\title{
The Future Direction of China's Cross-Border Insolvency Laws, Related Issues and Potential Problems
}

\begin{abstract}
The enactment of China's bankruptcy laws in 2006 was a necessary step in the development of its economy. This law represented a significant modernisation of the insolvency framework, supporting the transforming economy, but it was also a law of political expediency, for the enhancement of external relations. One aspect of the enhancement of external relations was the provision of cross-border insolvency rules. However this complex area of law was addressed in only one article, which was only a starting point, leaving many details unaddressed, and further reforms are required. In particular, it is desirable that the law provides a greater level of predictability as to the likely outcomes of cross-border insolvencies, to encourage inward trade and investment, as well as encourage external trade. Both inbound and outbound business dealings are important to China's continued economic development.
\end{abstract}

It is clear also, however, that insolvency law and practice is still a developing area for China. The establishment of a modern and unified system of insolvency laws was a big step for China, representing a sacrifice of tight controls on insolvencies, but the impact of this law in practice is only recently developing, with a loosening of state controls, after a very slow start. ${ }^{1}$ The establishment of a cross-border insolvency framework represents a further challenge; one that is likely to beset with considerable difficulties, as any further development of this law would potentially entail some further loss of control over proceedings, not least in outbound cases, and resistance may be anticipated. In keeping with China's historical approach to law-making in the area of bankruptcy law, it is likely that the cross-border insolvency framework

\footnotetext{
${ }^{1}$ Numbers of bankruptcies remain low, due to a government preference for mergers and restructurings and deregistrations as alternatives to liquidation and some courts placing restrictions on the acceptances of cases. However the Supreme People's Court reported an increase of $54 \%$ in bankruptcy cases in 2016, attributed in part to efforts to eliminate zombie companies and an upward trend was reported in the first half of 2017.
} 
will develop gradually and with caution. This article assesses the way forward in respect of cross-border insolvency laws, contending that an incremental approach over a period of years, in three broad stages, is required, with more developed and country specific approaches providing a link, or interim stage, between the clarification of the Article 5 and the formal adoption of the UNCITRAL Model Law in China.

\section{Introduction}

The enactment of the Chinese Enterprise Bankruptcy Law in 2006 was a notable milestone, representing the culmination of 12 years of legislative wrangling. The process of economic development, as well as the pressures of its external relations, meant that China could no longer forestall the introduction of a reformed, market driven, insolvency law to regulate its socialist market economy. ${ }^{2}$ The formal publication of this new Chinese insolvency legislation was a notable development in a number of respects. The presence of an insolvency law would have, at one time, been thought of as alien to the planned economy, ${ }^{3}$ as it would not have been thought that state-owned enterprises could be bankrupt, and their affairs did not tend to be conducted on credit and debit lines. ${ }^{4}$ The 2006 Law, on the face of it, provided a modern insolvency system, simple in details, along the lines of established systems elsewhere, with new innovations including administrators and creditors' committees. The new law also introduced a unified system, applying to both private enterprises and state owned enterprises (although not individuals), replacing a fragmented approach to insolvencies, which had also been necessitated by the vastly differing levels of economic development in the country.

\footnotetext{
2 R Parry and H Zhang, "China's New Corporate Rescue Laws: Perspectives and Principles" (2008) 8 JCLS 113-141

${ }^{3} \mathrm{~A}$ Tang, Insolvency in China and Hong Kong, A Practitioner's Perspective (Hong Kong, Sweet and Maxwell, Asia), 3.04; R Parry and H Zhang, "Introduction" in R Parry, Y Xu and H Zhang (eds), China's New Enterprise Bankruptcy Law (Ashgate, 2009), p 9.

${ }^{4}$ Wang Weiguo notes that transfers of funds and materials between SOEs were regarded as "adjustments in accordance with state plans", rather than as credits and debits: Wang Weiguo \& Roman Tomasic (eds), Reform of PRC Securities and Insolvency Laws (Beijing: Press of the China University of Political Science and Law, 1999), 9.
} 
Numbers of bankruptcies were initially remarkably low, arguably due to the high level of discretion accorded to the courts as to whether to accept bankruptcy cases, creditor reluctance to pursue proceedings and the involvement of government agencies through bailouts. ${ }^{5}$ However more recently, there has been a scaling-back of government support and there have been some significant cases, such as the 2009 bankruptcy of FerroChina, which had significant numbers of foreign creditors and foreign bond holders, although concerns have been expressed as to possible inequality of treatment and distortions owing to political factors. ${ }^{6}$ More recently, the Central Economic Work Conference in December 2015 encouraged the use of bankruptcy proceedings in respect of uneconomic and virtually dead SOEs and there was a significant increase in the number of bankruptcy cases opened in 2016 with a further steady increase reported in the first half of 2017. However, although there have also been major crossborder restructurings involving companies with significant assets in China these have typically been in respect of companies that are incorporated overseas and have been carried out under court-based restructuring laws outside China. $^{7}$

As China's booming trading grows in volume, in terms of both inbound and outbound trade, it is likely that there will be an increasing number of crossborder insolvency cases involving China. The 2006 law therefore included, in Article 5, a basic framework for cross-border insolvency cases of both kinds. This article can be viewed as a good start, or a first stage, in the development of Chinese cross-border insolvency laws. However this single article is

\footnotetext{
${ }^{5}$ Yujia Jiang, "The Curious Case of Inactive Bankruptcy Practice in China: A Comparative Study of U.S. and Chinese Bankruptcy Law" (2014) 34 Nw. J. Int'I L. \& Bus. 559.

6 Umesh Desai and Michelle Price, "Amid China slowdown, foreign creditors face bankruptcy riddle", Reuters Nov 30, 2015 8:14am EST.

${ }^{7}$ An example is that of such as that of Suntech, registered overseas but with significant Chinese assets, which entered liquidation in the Cayman Islands. "Suntech unit declared bankrupt" (2013, March 20) FT. The Cayman Islands liquidation was recognised under Chapter 15 in In re Suntech Power Holdings Co.; 14-10383, U.S. Bankruptcy Court, Southern District of New York (Manhattan). Interestingly, in that case, the prospect of Chinese insolvency proceedings was roundly rejected. See also the order under the Companies' Creditors Arrangement Act in respect of Sino-Forest, a company with the majority of its assets in China and a registered office in Canada Corporation Re Sino-Forest Corporation 2012 ONSC 7050 (12 December 2012), Superior Court of Justice (Ontario, Canada).
} 
arguably insufficient to deal with cross-border insolvencies on a long-term basis in China, since it is limited in application and lacks detailed guidance. Cross-border insolvency systems in more mature systems of insolvency laws, are commonly reaching what may be regarded as a third stage of development, explained below, and, just as it took those jurisdictions several years to reach this point, it will take many years for China to catch up.

This article considers Article 5 and the possible future development of crossborder insolvency laws in China, in three sections. Firstly, it identifies the weaknesses of Article 5 and how it may be reformed in future, drawing upon international experiences. Secondly, it considers how the Chinese law may build a more advanced approach, concentrating initially on developing a guideline framework for use with its most important trading partners. The clarification of Article 5 and the formulation of a guideline will potentially pave the way for a third and final stage, which is the formal adoption of the UNCITRAL Model Law in China. Most importantly, account must be taken of China's unique social and legal background and special characteristics, which must shape the reforms at each of the three recommended developmental stages.

\section{Cross-border Insolvency Related Issues and Potential Problems in China}

Before the enactment of the Chinese EBL 2006, the concept of cross-border insolvency did not exist in Chinese national legislation, unsurprisingly, given the nascent and patchy nature of even domestic insolvency legislation at that time. $^{8}$ Accordingly the Chinese legislators had not decided whether to follow the principle of universalism or to follow the principle of territorialism. ${ }^{9}$ This did not mean however that China had no cross-border insolvency cases. Such cases inevitably arose following the adoption of the opening up policies in

\footnotetext{
${ }^{8} \mathrm{R}$ Parry and H Zhang, "Introduction" in R Parry, Y Xu and H Zhang (eds), China's New Enterprise Bankruptcy Law (Ashgate, 2009), p 9-14.

9 Minkang Gu, "A Superior Win and an Inferior Loss: New Developments in Chinese Bankruptcy Laws and Regulations" (2008) 1 IJPR 130
} 
1978 and, as might be expected, early approaches were territorial and based on civil procedure laws.

Early reported examples were of inbound cases, where territorial approaches were adopted in cases concerning foreign companies. For example, in 1990 there was the Liwan District Construction Case, ${ }^{10}$ in which Guangzhou Intermediate People's Court applied a territorial approach so as to protect the interests of a Chinese party and thereby refused to recognise a Hong Kong representative who had been appointed under a Hong Kong insolvency proceeding. ${ }^{11} \mathrm{~A}$ territorial approach was again applied in the $\mathrm{BCCl}$ (Shenzhen Branch) Case in 1992, and Shenzhen Intermediate People's Court thereby made it possible for creditors in China to obtain repayment quickly and at a high level without participating in the $\mathrm{BCCl}$ worldwide liquidation proceedings. ${ }^{12}$ On the basis of these cases it might have been predicted that the Chinese courts would favour a territorial approach in dealing with crossborder insolvency cases. ${ }^{13}$ However, in the case of the $B \& T$ Ceramic Group s.r.l. (referred to as $B \& T$ ), the Foshan Intermediate People's Court granted recognition of an insolvency judgment made by an Italian court. An important factor in this case was a Treaty on Judicial Assistance in Civil Matters between the People's Republic of China and the Republic of Italy, and the Foshan court also made its decision on the basis of public policy and other factors. As far as is ascertainable, this case was the first case in which a foreign insolvency judgment was recognised by a Chinese court.

\footnotetext{
10 Liwan District Construction Company v. Euro-America China Property Limited, the defendant was a Hong Kong registered company which had concluded several contracts with the claimant. The claimant lodged a complaint in Guangzhou Intermediate People's Court based on the defendant's breach of contract. The case became more complicated when the defendant was wound up by a Hong Kong court.

11 Donald Lewis and Charles Booth, "Case Comment, Liwan District Construction Company v. Euro-America China Property Limted" (1990) 6 CLP 33-34

12 Jingxia Shi, "Chinese Cross-Border Bankruptcy Law: Status, Problem and Future Development” (中国的跨界破产法: 现状. 问题及发展) (2002) 1 CLS 117

${ }^{13}$ Rebecca Parry, Yongqian Xu and Haizheng Zhang, China's New Enterprise Bankruptcy Law (1 ${ }^{\text {st }}$ edn Ashgate, Surrey 2009) 341 and 329
} 
The $B \& T$ case might have been taken to offer an insight into a possible future approach to cooperation in cross-border insolvency cases in China. ${ }^{14}$ However, although the Foshan Court formally recognised its Italian counterpart's judgment, the Foshan court did not practically enforce the Italian court's judgment, reflecting the "immaturity of the insolvency regime in dealing with cross-border issues in China."15

Later, there was the outbound bankruptcy case of Guangdong International Trust Investment Corporation 1999 (referred to as the 'GITIC case'). GITIC was declared bankrupt by the Guangdong Province People's High Court and placed under the control of a liquidation group, under the EBL 1986. Importantly, when the liquidation group paid out a dividend in the bankruptcy no distinction was made between Chinese and foreign creditors. ${ }^{16}$ In the light of this approach, the Hong Kong High Court recognised the Guangdong High Court's insolvency proceeding against GITIC. This was an important case, indicating the importance of equal treatment of creditors as a prerequisite if outbound Chinese insolvency proceedings are to be recognised by foreign courts. ${ }^{17}$

\section{Stages of cross-border insolvency reforms}

There are arguably three stages to the development of cross-border insolvency laws under the following, broad, categorisation. The first stage is for a country to include in its legislation a provision that provides a basis for its courts to consider such cases. There are several examples of countries that have taken such an approach at an early stage, notably the United States in the, now repealed sections 304-306 of US Code, Title 11, Canada ${ }^{18}$ and

\footnotetext{
14 Jingxia Shi, "Chinese Cross-Border Bankruptcy Law: Status, Problem and Future Development” (中国的跨界破产法: 现状. 问题及发展) (2002) 1 CLS 118

${ }^{15}$ Qingxiu Bu, "China's Enterprise Bankruptcy Law (EBL 2006): Cross-border Perspectives" (2009) 18 IIR 187,190

16 Jingxia Shi, "Instance Analysis of the Extraterritorial Effect of China's Insolvency Proceeding" (我国破产程序域外效力的实例分析) (2002) 3 TPSL 41-45

${ }_{17}$ Rebecca Parry, Yongqian Xu and Haizheng Zhang, China's New Enterprise Bankruptcy Law (1 $1^{\text {st }}$ edn Ashgate, Surrey 2009) 341 and 340

${ }^{18}$ Bankruptcy and Insolvency Act, Part XIII.
} 
Australia. ${ }^{19}$ This is the stage which China has reached, at least on paper, although these other jurisdictions have largely moved on to "third stage" of similar frameworks based on the UNCITRAL Model Law. The second stage for China is likely to be the development of an approach to selected countries. A strong early example of such an approach is the Inter-Nordic Insolvency Convention. The European Union Regulation 20 provides the most sophisticated example, based on a high level of universality. In a more limited way, the UK section 426 offers a greater level of assistance but only to "relevant countries or territories". If this was the second stage for China it would potentially provide a stronger basis for the consideration of cases involving its closest trading partners and would reflect the incremental approach to reform that has often been taken in China. ${ }^{21}$ The third stage is acceptance of a more general approach to such cases under a standardised approach without geographical limitation. Some countries that have adopted the UNCITRAL Model Law may be regarded as having reached this third stage.

\section{Comment and Analysis of Article 5 of the EBL 2006}

The inclusion of Article 5, the first provision to address cross-border insolvencies, represents "a stride towards international cooperation between Chinese courts and foreign counterparts when a cross-border case is initiated." ${ }^{22}$ However the scope of Article 5 is limited and its terms are ambiguous. Article 5 consists of two paragraphs, respectively concerning the outbound effect of Chinese insolvency proceedings and the inbound effect of foreign insolvency proceedings in China. There is considerable progress to be made before China can move on from this first stage and this article, later, considers how the laws at this first stage may be augmented.

\footnotetext{
${ }^{19}$ Corporations Law, ss 580 and 581 and Bankruptcy Act 1986, s 29.

${ }^{20}$ Council Regulation of 29 May 2000 on Insolvency Proceedings (EC) No 1346/2000.

${ }^{21}$ Linda Yueh, Enterprising China: Business, Economic, and Legal Developments Since 1979 (OUP, 2011), 9; Hassane Cisse, Sam Muller, Chantal Thomas, Wang Chenguang (eds), The World Bank Legal Review: Legal Innovation and Empowerment for Development (World Bank, 2012), 175.

22 Rebecca Parry, Yongqian Xu and Haizheng Zhang, China's New Enterprise Bankruptcy Law (1 ${ }^{\text {st }}$ edn Ashgate, Surrey 2009) 341 and 342
} 


\section{a) The Outbound Effect of Chinese Insolvency Proceedings}

Outbound effects are addressed briefly in a provision that may be translated in the following terms: "insolvency procedures commenced in accordance with this Law are binding on the debtor's property located outside the territory of the People's Republic of China". This approach may be regarded as an example of a universalist approach, envisaging "a single forum applying a single legal regime to all aspects of a debtor's affairs on a worldwide basis". ${ }^{23}$ This Article provides a legal foundation in respect of claims to the debtor's assets situated outside of China. ${ }^{24}$ However, the effectiveness of this provision is, of course, out of China's hands, as it depends on overseas recognition of the law's extraterritorial effects. ${ }^{25}$ Essentially, China hopes that the foreign courts will recognise China's insolvency legal regime and the policies contained in China's insolvency proceedings.

A clearly defined Chinese insolvency proceeding with extraterritorial effect is often an important prerequisite and legal requirement for countries to recognise the Chinese insolvency proceedings. ${ }^{26}$ As the GITIC case suggests, this recognition is likely to depend as much on the manner in which foreign claims will be treated in the Chinese proceedings, as on the terms of paragraph 1 of Article 5. It should also be noted, as discussed later, that recognition can provide a basis for reciprocity, which is important in respect of inbound proceedings under paragraph 2 of Article 5, and this can provide an incentive in favour of recognition of such proceedings.

\footnotetext{
${ }^{23}$ As described in the landmark judgment of the late Tina Brozman, Bankruptcy Judge in Re Maxwell Communications Corporation plc, 170 B.R. 800, 816 (Bankr. S.D.N.Y. 1994), aff'd, 186 B.R. 807, 812-815 (S.D.N.Y. 1995) (Scheindlin USDJ), aff'd, 93 F.3d 1036 (2d Cir. 1996) (Cardamone, Circuit Judge).

${ }^{24}$ Rebecca Parry, Yongqian Xu and Haizheng Zhang, China's New Enterprise Bankruptcy Law (1st edn Ashgate, Surrey 2009) 341 and 341

$25 \mathrm{lbid}, 341$ and 341 . The recognition on 12th August 2014, of the Zhejiang Topoint Photovoltaic Co. Ltd. bankruptcy proceeding by New Jersey bankruptcy court as foreign main proceeding is encouraging.

${ }^{26}$ Emily Lee and Karen Ho, "China's New Enterprise Bankruptcy Law-A Great Leap Forward, But Just How Far?" (2010) 19 IIR 145, 172
} 
To augment the minimal detail of paragraph 1 of Article 5, it is arguably desirable for China to provide express powers for the Chinese courts or insolvency administrators to apply for recognition and assistance from foreign courts, as well as to explicitly stipulate the specific procedures as to how the administrator's powers may be exercised. It would be desirable if paragraph 1 expressly confirmed that the powers and obligations of insolvency administrators appointed by the Chinese courts also have extraterritorial effect, 27 in addition to setting out mechanisms for cooperation and communication between the office holder and the local courts. ${ }^{28}$ The inclusion of such provision would facilitate the handling of outbound cases, although it is also notable that foreign judges may lack the ability to act in the absence of an express statutory provision (this would also be the case for judges in China, in the absence of some express provision). ${ }^{29}$

It is also notable that Article 5, paragraph 1 makes no distinction between main and non main proceedings. A 'centre of main interests' approach to jurisdictional competence in respect of the opening of main insolvency proceedings is to be preferred, since it has regard to the actual circumstances of the debtor's commercial activities and in recent years it has become the commonly applied approach to the opening of main proceedings. For instance, Article 3(1) of the EU Insolvency Regulation stipulates that the courts of the Member State within the territory of which the centre of a debtor's main interests is situated shall have jurisdiction to open insolvency proceedings. In the case of a company or legal person, the place of the registered office shall be presumed to be the centre of its main interests in the absence of proof to the contrary.' Articles 2 of the Model Law and Paragraph

\footnotetext{
${ }^{27}$ An example of a provision giving such authorization is Article 5 of the UNCITRAL Model Law, giving authorization for an office holder to act in a foreign state. This Article has been applied in the UK by the CBIR 2006, regulation 2. Article 5, as applied, authorizes a British officeholder to act in a foreign State on behalf of a proceeding under British insolvency law, as permitted by the applicable foreign law. Using the same Model Law, Section 1505 of Chapter 15 of US Bankruptcy Code authorizes a trustee or another entity (including an examiner) to act in a foreign country.

${ }^{28}$ Articles 25 to 27 of the UNCITRAL Model Law, as adopted in both Great Britain and the US, stipulate provisions of cooperation and direct communication between the court, the insolvency administrator (the officeholder or trustee in the case of the CBIR and the Chapter 15 respectively) and foreign courts and representatives and they are applied in Articles 25 to 27 of the CBIR 2006 and Sections 1525 to 1527 of the Chapter 15 respectively.

29 See Paragraph 213 of the UNCITRAL Model Law Enactment Guide
} 
72 of its Enactment Guide have similar stipulations. Accordingly, for China, the adoption of the concept of non-main proceedings, in cases where the COMI is in another jurisdiction, as part of its cross-border insolvency legal framework would bring its approach into line with the dominant approach that is developing internationally, even while China remains at the first stage of development of cross-border insolvency laws. In order to make use of this concept and its accompanying system in determining jurisdictional issues, a first step that China should take is to rectify the existing flaw in Paragraph 1 of Article 5 so as to make it conform to the requirement of non-main proceedings only having territorial effect.

\section{b) The Inbound Effect of Foreign Insolvency Proceedings in China}

The simple declaration in Article 5 in respect of the universality of outbound proceedings contrasts markedly with the more complex and guarded approach to inbound proceedings, that is, those where an application is filed on the basis of a legally effective foreign insolvency judgment or decision in respect of the debtor's assets located with the territory of the P.R.C. Here a modified approach to universality ${ }^{30}$ is taken to enable the Chinese courts to grant recognition and enable enforcement in certain circumstances. ${ }^{31}$ "Where a judgment or decision entered into by a foreign court regarding the debtor's property located within the P.R.C.'s territory requires acceptance and execution by a Chinese Court, the Chinese Court shall, based upon a relevant petition or request, consider the foreign judgment or decision and render the ruling of recognition and permission for enforcement in accordance with the international agreements to which the P.R.C. is a party, or based on a mutual reciprocity principle, after ascertaining that the proceeding does not violate the basic principles of the laws of the People's Republic of China, does not damage the sovereignty, safety or social public interests of the state and does

\footnotetext{
$30 \mathrm{lbid}, 816$.

${ }^{31}$ Emily Lee and Karen Ho, "China's New Enterprise Bankruptcy Law-A Great Leap Forward, But Just How Far?" (2010) 19 IIR 145, 172; Qingxiu Bu, "China's Enterprise Bankruptcy Law (EBL 2006): Cross-border Perspectives" (2009) 18 IIR 187,191; Rebecca Parry, Yongqian Xu and Haizheng Zhang, China's New Enterprise Bankruptcy Law (1st edn Ashgate, Surrey 2009) 341 and 342
} 
not damage the legitimate rights and interests of the debtors within the territory of the People's Republic of China."32

This may be regarded as an approach of modified universality. Such an approach is not unusual in jurisdictions with modern insolvency systems, enabling the fairness of the foreign proceedings to be evaluated and giving scope for the interests of local creditors to be protected, and it is not surprising that China has taken this approach. Article 5 can therefore only be viewed as having established an "in principle" framework for international cooperation in cross-border insolvency in China ${ }^{33}$ and the way forward at present remains uncertain. Generally, China's stance in terms of the recognition of the extraterritorial effect of foreign insolvency proceedings is very vague, non-specific and conservative, and a Chinese court is very unlikely to deviate from the promulgated approach, based on either the treaties to which China is a party or on the basis of mutual reciprocity. Nonetheless the granting of recognition can facilitate cooperation in crossborder insolvency cases ${ }^{34}$ and recent case law is encouraging. Although no reference to Article 5 was made by the Supreme Court in Thumb Environmental Technology Group v Sino-Environment Technology Group the court recognised the power of a foreign office holder to represent the company in respect of which he was appointed and held that the powers of the office holder would be governed by the laws of the place where the company was registered, in this instance Singapore. ${ }^{35}$ As this case indicates, civil procedure laws can provide an alternative basis for recognition of the position and powers of a foreign office holder.

In line with normal Chinese processes for the development of the law, China could clarify Paragraph 2 of Article 5 by means of a judicial interpretation by

\footnotetext{
32 See Paragraph 2 of Article 5 of the EBL 2006

33 In the draft of the EBL 2006, there was a cross-border insolvency chapter. However, for the reason of maintaining social stability, only one broad article was included in the EBL 2006.

${ }^{34}$ Jinsong Yu and Jingxia Shi, "On Several Legal Issues of the Insolvency Involving Foreign Elements” 涉外破产的若干法律问题 (1996) 4 CSS 108-109

${ }^{35}$ [2014] No 20 Final Judgment of the Fourth Civil Division of the Supreme People's Court, applying the Law on the Application of Law for Foreign-related Civil Legal Relationships of the People's Republic of China, Article 14.
} 
the Supreme People's Court to provide Chinese courts with more concrete regulation in terms of its discretion in the recognition and enforcement of legally effective foreign insolvency judgments and decisions. This possibility is considered further in Section IV, below.

\section{Priority and Review Criteria in Respect of Recognition of Foreign Insolvency Proceedings}

The inclusion of this detail is required to resolve the problems of concurrent insolvency proceedings being exercised over the same debtor in practice. According to Article 3 of the EBL 2006, a bankruptcy case shall be governed by the court where the relevant debtor is domiciled. ${ }^{36}$ However domicile is a concept that is open to manipulation, for example in the case of a "letterbox" company, that uses incorporation for reasons of convenience and actually carries out no further activity in the jurisdiction in question. As noted, the concept of COMI offers an approach to jurisdictional competence to open main proceedings that has wide international acceptance.

\section{Recognition and the Retrospective Effect of Foreign Insolvency Proceedings}

As a general rule, in order to comply with the spirit of international cooperation in cross-border insolvencies, ${ }^{37}$ engender reciprocity and align with the exclusive jurisdiction stipulated in Article 3 of the EBL which states that "an insolvency case shall be governed by the court where the relevant debtor is domiciled", the Chinese courts should be open to recognition of the extraterritorial effect of insolvency proceedings initiated in the debtor's domicile. ${ }^{38}$ In particular, the recognition of foreign proceedings may help in the control of fraud. If the Chinese court does not recognise the legal effect of initiation of the proceedings, fraudulent trading and repayment of individual

\footnotetext{
${ }^{36}$ See Article 3 of the EBL 2006

${ }^{37}$ See Article 2 (b)(c), Article 16 (3) of the Model Law

${ }^{38}$ Xinxin Wang and Jianbin Wang, "Analysis About China's Acknowledging Extraterritorial Effect System of Foreign Bankruptcy Procedure and its Improvement” (我国承认外国破产程序 域外效力制度的解析及完善)'(2008) 6 LSM 10, 10-12
} 
creditors between the two time points may be difficult to control, which would lead to an ineffectiveness of international cooperation in cross-border insolvency. ${ }^{39}$

There is uncertainty as to whether, in a case where foreign proceedings are recognised, this recognition will have retrospective effect, and whether recognition has an effect on the disposal of property by a debtor within the Chinese border and repayment of debts to individual creditors between the time when the insolvency proceeding has been initiated in a foreign country and the time when the Chinese court recognises the judgment. ${ }^{40}$ It is likely that, for the purpose of protecting the legitimate rights of domestic creditors, China will expressly refuse the retrospective effect of a foreign insolvency proceeding except perhaps where recognition would strengthen international cooperation to circumvent a debtor's fraudulent conduct.

The proceedings should preferably be in the spirit of Article 17 (3) of the Model Law, which stipulates that "an application for recognition of a foreign proceeding shall be decided upon at the earliest possible time." 41 Delays can cause uncertainties and a loss of value of the estate. In a similar vein, an expedited order granting "provisional relief" 42 may be desirable in urgent cases, to preserve the debtor's estate, or protect the interests of creditors, including Chinese creditors. Such an order is however unprecedented in Chinese laws and it is desirable that express provision be made to enable such an order to be made upon the request of a foreign office holder or court.

\section{Examination According to the Relevant International Treaties That China Has Concluded or Acceded to or According to the Principles of Reciprocity}

\footnotetext{
$39 \mathrm{lbid}$. This is a point which was made, long ago, by Jitta, International Bankruptcy Codification (1895) 7 Jur Rev 305.

${ }^{40}$ See further at: Xinxin Wang and Jianbin Wang, "Analysis About China's Acknowledging Extraterritorial Effect System of Foreign Bankruptcy Procedure and its Improvement" (我国承 认外国破产程序域外效力制度的解析及完善)'(2008) 6 LSM 10, 10-12

41 See Article 17 (2) of the Model Law

42 See e.g. Article 19 (1) of the Model Law
} 
Paragraph 2 of Article 5 establishes a two part approach to the examination and acceptance of foreign bankruptcy judgments and decisions. The first provides a basis for recognition, which requires that the judgment or decision should be in accordance with international treaties and reciprocity. The second examines various public policy factors, requiring that the judgment or decision must not be contrary to the basic principles of Chinese laws; and it should not impair sovereignty, national security, social public interests and the legitimate rights and interests of Chinese creditors.

There is little case law to indicate how the courts will approach this provision. Regarding the first part, it is notable that, until now, China has not become a signatory to any bankruptcy-specific international treaties. It is likely that, instead, reference will be made to the numerous bilateral treaties on judicial assistance in civil and business matters that China has entered into, either on the basis that these are international treaties, or on the basis that they provide evidence of reciprocity. To date, there are over 40 countries which have concluded bilateral treaties in civil and business matters with China. Although these treaties are not bankruptcy specific, they do not typically exclude bankruptcy matters. Arguably the Chinese courts should follow the terms of the bilateral treaties in scrutinizing the requests to give extraterritorial effect to foreign insolvency proceedings, so as to decide whether or not to grant recognition. As previously noted, in the pre-EBL case of $B \& T$ Ceramic Group $S R L$, the Foshan Intermediate People's Court of Guangdong granted recognition to an insolvency judgment made by an Italian court, primarily on the basis of a Treaty on Judicial Assistance in Civil Matters between the People's Republic of China and the Republic of Italy, as well as on the basis of public policy and other factors. ${ }^{43}$ Similarly, the two part approach under paragraph 2 indicates that the existence of a bilateral treaty is unlikely to be sufficient in itself, rather the court may have regard to public policy factors and must be satisfied that the judgment does not contravene the ordinary principles of Chinese law, that it is not detrimental to state sovereignty or

\footnotetext{
${ }^{43}$ See further Xinxin Wang and Jianbin Wang, "Analysis About China's Acknowledging Extraterritorial Effect System of Foreign Bankruptcy Procedure and its Improvement" (我国承 认外国破产程序域外效力制度的解析及完善)'(2008) 6 LSM 10, 10-12
} 
security and social public interests and that it does not harm the legitimate rights of interests of Chinese creditors. It should be added that the $B \& T$ case was decided at the time of China's accession to the WTO and it is unclear to what extent the decision may have been influenced by a need to show openness to foreign trade. ${ }^{44}$ It is unclear how a case would be approached in the absence of similar political impetus.

In the event that there is no bilateral treaty on judicial assistance in civil and business matters, or no bilateral treaty is considered applicable to Article 5, the Chinese courts are required conduct their examination on the basis of the principle of reciprocity. Reciprocity is a requirement in cases where recognition and enforcement of a foreign judgement is requested in China in the absence of a bilateral treaty. ${ }^{45}$ Existing examples do not augur well as a lack of reciprocity has commonly been used in China as a basis for a refusal to recognise a foreign judgment. ${ }^{46}$ Reciprocity, broadly, entails an examination of whether the other state would recognise the effects of Chinese proceedings in similar circumstances. Regard would therefore be had to how strictly a request for recognition would be considered in that other state. Under a strict approach to reciprocity, evidence of actual cooperation (whether in a case involving outbound Chinese proceedings, or, more loosely, proceedings from another country) might be required, although arguably it is preferable for reciprocity to be presumed unless there is evidence to the contrary. ${ }^{47}$

To this end, it is notable that although reciprocity is a factor which has historically played an important role in cross-border insolvency proceedings,

\footnotetext{
44 Wenliang Zhang, "Recognition and Enforcement of Foreign Judgments in China: A Call for Special Attention to Both the "Due Service Requirement" and the "Principle of Reciprocity"' (2013) 12 Chinese Journal of International Law 143, 161.

${ }^{45}$ Civil Procedure Law of the People's Republic of China, art 268 (1991). Wenliang Zhang, "Recognition and Enforcement of Foreign Judgments in China: A Call for Special Attention to both the 'Due Service' Requirement and the 'Principle of Reciprocity'” (2013) 12 Chinese Journal of International Law 143.

46 Jerome A Cohen, "Settling International Business Disputes with China: Then and Now" (2014) 47 Cornell International Law Journal 555, 566-7.

47 See Jay Lawrence Westbrook, "Theory and Pragmatism in Global Insolvencies: Choice of Law and Choice of Forum", (1991) 65 Am. Bankr. L.J. 457, 468 regarding concepts of reciprocity.
} 
and still has a role in some jurisdictions, ${ }^{48}$ in more recent years, in order to facilitate international cooperation, the UNCITRAL Model Law, the EU Insolvency Regulation and most of the laws enacted by countries such as the US, UK, Australia and Canada and other Model Law adopting countries have almost completely abandoned any reciprocity requirement. For this reason, it is arguable that proceedings that have been opened in a country which has adopted the UNCITRAL Model Law, or which has similarly abandoned any reciprocity requirement, should logically be regarded as meeting the reciprocity requirement under Article 5.49

Although it is unlikely in the short term, an abandonment of a requirement of reciprocity would be a logical step for the development of the cross-border insolvency system. This would not cause Article 5 to be an open gateway, rather the focus would turn instead to whether the foreign proceedings met the public policy requirements.

\section{Interpretation and Application of Public Policy Requirements}

Article 5 stipulates a very broad public policy reservation, namely that a foreign insolvency judgment or decision can be recognized and enforced only if it does not violate the basic principles of the laws of the People's Republic of China, does not damage the sovereignty, safety or social public interests of the state and does not damage the legitimate rights and interests of the creditors within the territory of the People's Republic of China. As might be expected, this is a more potentially restrictive approach than its equivalent under the EU Insolvency Regulation, which contains a provision ${ }^{50}$ enabling a Member State to refuse to recognise proceedings opened in another Member State on the basis that they are manifestly contrary to public policy, an exception which has been narrowly construed and appears limited to, for

\footnotetext{
${ }^{48}$ For example Switzerland,

${ }^{49}$ Xinxin Wang and Jianbin Wang, "Analysis About China's Acknowledging Extraterritorial Effect System of Foreign Bankruptcy Procedure and its Improvement” (我国承认外国破产程序 域外效力制度的解析及完善)'(2008) 6 LSM 10, 10-12

50 Council Regulation of 29 May 2000 on Insolvency Proceedings (EC) No 1346/2000, Art 26.
} 
example, the fairness of legal processes. ${ }^{51}$ A similar exception, where the proceedings are manifestly contrary to public policy, appears in the UNCITRAL Model Law and has been adopted in the versions of the Model Law adopted by countries such as the US and the UK. Again, this appears to be a narrow exception and it ought not to apply, for example, simply because creditors would be treated differently under one system, as compared with another. ${ }^{52}$ Under a similar approach to public policy a Chinese court would not be able to refuse recognition merely on the basis that different legal rules exist between Chinese laws and relevant foreign counterparts. However a more restrictive approach is likely.

It is notable that Article 5 is expansive and it also stipulates that the recognition of a foreign insolvency judgment or decision should "not damage the legitimate rights and interests of the creditors within the territory of the People's Republic of China". The legal basis of such rights and interests is likely to be based on domicile, as Article 3 of the EBL 2006 stipulates that "bankruptcy cases shall be under the jurisdiction of the Chinese court at the place of the debtor's domicile." In a case where the creditor's domicile is located within the territory of China, the legal basis of the legitimate rights and interests of the creditors refers to all rights and interests provided by all relevant Chinese laws, including the EBL 2006, since the Chinese court has jurisdiction over the insolvency proceedings, and the foreign proceedings should not impact upon these. If, however, the debtor's domicile is not located within the territory of China, other Chinese civil laws are applied instead of the EBL 2006 and in addition to foreign insolvency laws under a foreign insolvency judgment, since the Chinese court does not have the jurisdiction over the insolvency proceedings in this scenario. The term "damage to legitimate rights and interests of the debtors" can be interpreted as applying where "Chinese creditors cannot be treated fairly, therefore cannot enjoy the

\footnotetext{
51 Re Eurofood IFSC [2006] 1 Ch 508, para 66.

52 See e.g. McGrath and others v Riddell and another [2008] UKHL 21. See Michael A. Garza, "When is Cross-Border Insolvency Recognition Manifestly Contrary to Public Policy" (2015) 38 Fordham International Law Journal 1587.
} 
same rights and interests" 53 as local creditors. Arguably some unfairness based on differential treatment is required and not simply that creditors receive less under one system than they would under another. However a narrow approach to public policy may be taken by the courts.

\section{The Future Developmental Direction of China's Cross-Border Insolvency Regime}

Article 5 represents only a starting point and there is considerable progress to be made at this first stage of development of the cross-border insolvency laws. The further development of these laws should arguably focus initially on the augmentation of Article 5. The next stage can then be the development of a cooperation guideline with its closest trading partners. This can then pave the way for the adoption of the UNCITRAL Model Law.

\section{Completing Stage 1: The Issuing of a Judicial Interpretation to Clarify the Uncertainties in Article 5}

Gaps in Article 5 present "obstacles towards effective cooperation in the administration of the cross-border insolvency proceedings." 54 It may be anticipated that any vagueness and uncertainties in Article 5 of the EBL 2006 can initially be clarified by means of a Judicial Interpretation of the Enterprise Bankruptcy Law 2006. Judicial interpretations are commonly used to augment legislation in China. For example, details regarding insolvency practitioner appointments and remuneration were addressed in this manner. ${ }^{55}$ In China, three competent authorities can issue judicial interpretations, namely the Standing Committee of the National People's Congress, the Supreme People's Court and the Supreme People's Procuratorate. The judicial

\footnotetext{
${ }^{53}$ Xinxin Wang and Jianbin Wang, "Analysis About China's Acknowledging Extraterritorial Effect System of Foreign Bankruptcy Procedure and its Improvement” (我国承认外国破产程序 域外效力制度的解析及完善)'(2008) 6 LSM 10, 10-12

${ }^{54}$ Emily Lee and Karen Ho, "China's New Enterprise Bankruptcy Law-A Great Leap Forward, But Just How Far?" (2010) 19 IIR 145, 176

55 See R Parry, "Administrator: Appointment and Remuneration" in R Parry, $\mathrm{Y} X u$ and $\mathrm{H}$ Zhang (eds), China's New Enterprise Bankruptcy Law (Ashgate, 2009), Chapter 6.
} 
interpretation has legal validity and is enforceable by law, but it cannot conflict with the Constitution and Laws by reason of the priority of the law at the higher level over that at the lower level. ${ }^{56}$

As was mentioned above, such judicial interpretation can include the clarifications of matters including the priority and review criteria in respect of recognition of foreign insolvency proceedings, the recognition process and the retrospective effect of foreign insolvency proceedings, the examination of foreign proceedings according to the relevant international treaties that China has concluded or acceded to or according to the principles of reciprocity, interpretation and application of reservation of public order and legitimate rights and interests of the creditors. However, such an interpretation can only clarify Article 5 and it would arguably only be suitable as an initial step towards providing the level of cooperation that will be required under the effective legal practice of China's cross-border insolvency. The next stage would be the formulation of a soft-law cooperation guideline with the content of "cooperation language". 57

\section{Stage 2: Formulation of a Cooperation Guideline}

The development of a cooperation guideline would enable cross-border insolvencies in China to be more effectively deal with. Such a guideline would, arguably be likely, initially, to be restricted to China's closest trading partners. It might be wondered why the adoption of the Model Law is not the next stage. Indeed it must be predicted that sooner or later China will formally adopt the Model Law, reaching the third stage. However, due to some reasons uniquely attributed to the special characteristics of China (as were explained above), this third stage will take a long time to achieve in practice. This cooperation guideline will be more practicably realisable if it initially applies in relation to selected jurisdictions with whom China has close dealings, similar to the approach taken by some countries with mature cross-border insolvencies at

\footnotetext{
${ }^{56}$ Wei Li, "Judicial Interpretation in China” (1997) 5 WJI LDR 87, 87-88

57 Steven Arsenault, "Leaping Over the Great Wall: Examining Cross-Border Insolvency in Chinese Corporate Bankruptcy Law" (2011) 21 IICLR 1, 22
} 
earlier stages in the development of their laws. At this second stage, it is arguably preferable for China to take a flexible measure, developing a cooperation guideline of a soft-law nature, to deal with both inbound and outbound cross-border insolvencies involving key trading partners.

\section{Suggested Chinese Cooperation Guideline in Cross-Border Insolvency}

One way to progress the development of a cross-border insolvency regime, while stopping short of legislative intervention, would be the adoption of a non statutory instrument to act as a guideline. The United States experience is instructive here. Non statutory instruments played an important role in facilitating the adoption of the UNCITRAL Model Law in the US and they remain important post-adoption. Notably, the US did not rush to adopt the Model Law, after its formal publication in 1997. Instead, advantage was taken of non-governmental organizations' legislation and practices to successfully accomplish the legal transformation several years later. It can be said that the formal adoption of the UNCITRAL Model Law in the US in 2005 took a long time for what was an uncontroversial law reform, the delay being due to political reasons, ${ }^{58}$ but the adoption of this law is likely to be more difficult for China. Ultimately the Model Law was adopted in the United States almost verbatim as Chapter 15 of the United States Bankruptcy Code, ${ }^{59}$ while, as discussed below, China is likely to take a more cautious approach.

Non statutory guidelines remain important in the United States. A "Principles of the Law, Transnational Insolvency" project, has been developed by the American Law Institute (ALI).These principles were originally developed for use in relation to NAFTA countries, however they "now apply generally to provide interpretation and guidance on various cross-border insolvency issues

\footnotetext{
58 See Elizabeth J Gerber, "Not All Politics Is Local: The New Chapter 15 to Govern Crossborder Insolvencies" (2002-2003) 71 Fordham Law Review 2051, 2054.

59 Jay Westbrook, "An Empirical Study of the Implementation in the United States of the Model Law on Cross-border Insolvency" (19, October 2012) $<$ http://papers.ssrn.com/sol3/papers.cfm?abstract id=2162964 > accessed May 20, 2013
} 
that are left unclear in Chapter 15."60 In addition, from the year of 2006 to the present, in the absence of clear national and regional legal rules to deal with procedural alignment of cross-border insolvency cases in a number of countries across the globe, the American Law Institute, together with the International Insolvency Institute has sponsored a global research project with the purpose of formulating "Global Principles for Cooperation in International Insolvency Cases". 61

The above two intertwined and interactive routes jointly contribute to the development and improvement of the US cross-border insolvency regime. In the process of the improvement of the Chinese cross-border insolvency regime, it is strongly suggested that great attention should be paid to this US experience. Although China is a civil law country, the emulation of this approach is still arguably achievable. In fact, China has already started a process of interaction between governmental legislation and nongovernmental legislation. For instance, a Model Law of Private International Law of the People's Republic of China 2000, drawn up by Chinese Institute of Private International Law (CIPIL), was supposed to be used only for reference by the governmental legislative and judicial bodies or other government departments working for foreign affairs. ${ }^{62}$ However, this soft-law Model Law of Private International Law of China was largely adopted in the foreign-related part of the draft Civil Code of China 2002. ${ }^{63}$ Equally plausibly, in the domain of cross-border insolvency, China might feasibly make use of the function of professional institutions, firms and practitioners. Cross-border insolvency legislation is both specialised and complex, for the reason that it requires lawmakers well versed in cross-border insolvency rules, specialized in both legal professional knowledge and accounting professional knowledge and

\footnotetext{
60 John Barrett, Johnathan Bolton and Robert Tucker, "Risks and Problems of Forum Selection in a Cross-Border Insolvency Case" (2009) 4 NARII 1, 4

61 See further lan Fletcher and Bob Wessels, "A Final Step in Shaping Rules for Cooperation in International Insolvency Cases" (2012) 5 ICR 283, 283

62 See further at: the Preamble of the Model Law of Private International Law of the People's Republic of China 2000

63 The Civil Code of China is still in its proposed draft period and has not yet been formally introduced.
} 
having abundant experiences in handling insolvency cases. ${ }^{64}$ In addition, the drafting of cross-border insolvency legislation requires careful consideration for the reason that it touches upon the protection of domestic interests as well as requiring cooperation and coordination between the different national courts. In every country including China, the non-governmental institutions are endowed with the strengths of relatively sophisticated insolvency professionals and knowledge and may have access to more flexible legislative tools to circumvent the obstacles in the domain of cross-border insolvencies.

One way in which professional expertise may be called upon to augment the skeletal cross-border insolvency legislation would be for the Chinese Institute of Private International Law, as one of the most influential Chinese nongovernmental academic organizations, to bear the responsibility to draw up a Chinese soft-law cooperation guideline in cross-border insolvency. After the publication of this cooperation guideline, the Chinese official legislatures, judicial authorities or other relevant government departments could emulate the US approach of interaction between governmental legislations and this non-governmental cooperation guideline. If, in the light of legal practice, certain provisions of the Chinese cooperation guideline showed inadaptability or otherwise unsuitability, then these provisions could be revised or abolished. The ultimate aim of this cooperation guideline would be to promote and supplement the implementation of Article 5 of China's EBL 2006 and its upcoming judicial interpretation, and to play a transitional role to smooth the way for the eventual adoption of the UNCITRAL Model Law in China.

\section{Main Content of the Chinese Cooperation Guideline in Cross-Border Insolvency}

China's cooperation guideline would arguably have two main functions. One would be to provide guidance as to the appropriate forum and applicable law in a particular case. The guideline could stipulate different solutions in respect of cross-border insolvency legal disputes between China and its major

\footnotetext{
${ }^{64}$ American Law Institute, Principles of Cooperation Among the NAFTA Countries ( $1^{\text {st }}$ edn Juris Publishing, Inc New York 2003) 1
} 
trading partners, under provisions that are analogous to the rules of remission and transmission in the private international law. For instance, in order to regulate the cross-border insolvency disputes between China and America, the guideline could stipulate that these China-US disputes can refer to the US Chapter 15 as a guideline. The other is to provide substantive provisions for cases that are handled under the guidelines. It would be important to stipulate the relationship between the hard-law and this soft-law guideline. It is arguable that if we regard Article 5 of the EBL 2006 and its proposed judicial interpretation as the hard-law main body, then we can call this cooperation guideline a soft-law supplement.

\section{i) Explicitly Excluding Certain Types of Debtors From the Application Scope of China's Cooperation Guideline}

In the Chinese context the categories of excluded debtors include natural persons (although personal insolvency legislation may soon be introduced on a regional basis), financial institutions such as banks and insurance companies, and public utility companies, reflecting the exclusions under the EBL. In contrast, both of the Model Law and the EU Insolvency Regulation apply to insolvency proceedings whether the debtor is a natural person or a legal person. ${ }^{65}$ This is mainly because systems of natural person bankruptcies are well established in western countries. However, China does not have a historical tradition and lawmaking experience of natural person bankruptcy. Indeed such bankruptcies have been thought of as culturally alien and therefore it is arguable that they should be excluded entirely, as they are from the scope of the EBL, until such time as they are introduced. ${ }^{66}$

In addition, financial institutions such as banks and insurance companies should be also excluded from the application scope of the proposed Chinese cooperation guideline. Precisely because of the particularity of financial institutions, the Model Law adopting counties, such as the UK and the US

\footnotetext{
65 See further at Recital (9) of the EU Insolvency Regulation

66 Paragraph 66 of the UNCITRAL Model Law Enactment Guide refers only to the possible exclusion of consumer bankruptcies.
} 
exclude financial institutions from the scope of application of their crossborder insolvency legislations, as does the EU Insolvency Regulation, and consequently the EU has addressed such institutions by means of special directives, namely, the EU Directive on the Reorganization and Winding-Up of Credit Institutions (2001/24/EC) and the EU Directive on the Reorganization and Winding-Up of Insurance Undertakings (2001/17/EC). In China, Article 134 of the EBL 2006 established on a preliminary basis the legal framework for the insolvencies of financial institutions, but it did not refer to the crossborder insolvencies of financial institutions. For this reason, for the improvement of this legal framework, it is appropriate to consider the principles that should apply in the event of a cross-border insolvency of a financial institution. Cross-border financial institution insolvencies arguably require global solutions, given the interconnected nature of financial markets.

\section{ii) Clear Stipulation of the Jurisdiction and Applicable Law in Cross-Border Insolvency Proceedings in China}

A Chinese cooperation guideline should clearly stipulate means for determining the appropriate jurisdiction in respect of the opening cross-border insolvency cases. In this regard, the obvious approach is to adopt the concept of centre of main interests, "COMl", that is widely employed in cross-border insolvency instruments, as previously discussed, and the concept of an "establishment" in respect of non-main proceedings, as under both the Model Law and the EU Regulation. ${ }^{67}$ Unlike main proceedings, non-main proceedings merely have territorial effect to cover the debtor's assets located within the territory of the state that opens such proceedings. They may, to a large extent, be regarded as a complication to be avoided, with cases more efficiently handled by employing instead the extraterritorial effects of the main proceedings to deal with the assets in the relevant jurisdiction.

\footnotetext{
${ }^{67}$ See Article 17 (3) of the UNCITRAL Model Law and Article 3 (2) of the EU Insolvency Regulation
} 
The terms "COMI" and "establishment" are both very important as the Model Law's criteria of recognition of foreign insolvency proceedings and the application of measures for relief. ${ }^{68}$ As terms in common usage and with developing approaches to their common interpretation, it is desirable that these terms should be adopted more widely, including under any Chinese cooperation guideline. Therefore, under the guideline, it would be desirable for foreign proceedings to be recognized either as foreign main proceedings or foreign non-main proceedings on the basis of these concepts. ${ }^{69}$ If a foreign proceeding was recognized as a foreign main proceeding, the guideline would provide, as Model Law provides, an automatic stay of proceedings by creditors against the foreign debtor's assets. ${ }^{70}$ If a foreign proceeding was recognized as a foreign non-main proceeding, the guideline would provide, as the Model Law provides, that all reliefs are discretionary. ${ }^{71}$ As under the EU Insolvency Regulation, main proceedings would have extraterritorial effect, whereas the effects of non-main proceeding would be restricted to the assets of the debtor situated within the territory of the state where non-main proceedings were opened. ${ }^{72}$

There would be two likely purposes for foreign non-main proceedings, if employed under a Chinese cooperation guideline. First, non main proceedings could be opened in the interests of Chinese creditors after the recognition of foreign main insolvency proceedings by a Chinese court, rather than Chinese creditors having to participate in those foreign proceedings so as to obtain repayment. This would primarily be a protectionist measure, reflecting that claiming in foreign proceedings is not only inconvenient for Chinese creditors, but also would not be conducive to the protection of the legitimate rights and interests of Chinese creditors, for the reason that different national insolvency laws have different priorities in respect of the

\footnotetext{
68 See Paragraph 15 of the UNCITRAL Legislative Guide on Insolvency Law 2006

69 See Article 17 (2) of the UNCITRAL Model Law

70 See Paragraph 126 of the UNCITRAL Model Law Enactment Guide

71 See Paragraph 153 of the UNCITRAL Model Law Enactment Guide

72 See Article 27 of the EU Insolvency Regulation
} 
claims of creditors. ${ }^{73}$ Second, after the recognition of foreign main insolvency proceeding by a Chinese court, a foreign insolvency representative might also request that the Chinese court assists in the implementation of the foreign insolvency proceeding and liquidation of the debtor' assets located within China, and a local liquidator may be better able to accomplish this if secondary proceedings are opened in China. ${ }^{74}$ Preferably, the cooperation guideline should imitate the Model Law's provisions in terms of enabling the court to cooperate and coordinate with foreign courts or foreign representatives in the situation of concurrent proceedings regarding the same debtor.

The introduction of the distinction between main and non-main insolvency proceedings is arguably the core issue for China in the further development of its legislation concerning the recognition of the extraterritorial effect of foreign insolvency proceedings. The employment of such concepts would primarily help to safeguard the legitimate rights and interests of Chinese creditors ${ }^{75}$ but they could also be conducive to better enforcement of foreign insolvency judgments and better assistance of foreign insolvency proceedings to realize their extraterritorial effect. ${ }^{76}$ The distinction between main and non-main proceedings is reasonable and workable, and it can fill one of the legal blanks in China's EBL 2006.

A Chinese cooperation guideline should also explicitly stipulate the applicable law in cross-border insolvency proceedings, since insolvency is often specified as an exception to more general choice of law rules and "instead the insolvency-specific doctrines of universality and territoriality have framed the discussion of choice of law issues." 77 The approach taken by UNCITRAL in its "Legislative Guide on Insolvency Law" is that, in normal situations, the

\footnotetext{
${ }^{73}$ Xinxin Wang and Jianbin Wang, "Analysis About China's Acknowledging Extraterritorial Effect System of Foreign Bankruptcy Procedure and its Improvement" (我国承认外国破产程序 域外效力制度的解析及完善)'(2008) 6 LSM 10, 13

74 lbid

75 lbid

${ }^{76}$ See also at 5.2.1 and 5.2.2

77 Hannah Buxbaum, "Rethinking International Insolvency: the Neglected Role of Choice of Law Rules and Theory" (2000) 36 SJIL 23, 25
} 
insolvency proceedings are regulated by the law of the state in which those insolvency proceedings were opened (the lex fori concursus) and in special situations, there are some exceptions to the application of the lex fori concursus. ${ }^{78}$ The application of the lex fori concursus provides certainty as to the applicable law in respect of the effects of the proceedings, including in relation to creditor entitlements, the treatment of claims, the treatment of contracts and the avoidance of vulnerable transactions, reflecting the goals of insolvency laws in that state and minimising the extent to which litigation is necessary to determine the applicable law. "Thus, in many circumstances the application of the lex fori concursus for insolvency effects may reduce costs and delays and therefore maximize the value of the insolvency estate for the benefit of all creditors." 79 This approach provides the logical model for the development of the Chinese system and China could stipulate as a general principle that the lex fori concursus is the applicable law, applying to all aspects of the commencement, conduct, administration and conclusion of those insolvency proceedings. ${ }^{80}$.. However, UNCITRAL has also noted that some exceptions may be necessary in determining the effects of an insolvency on valid and effective rights and claims, for example in relation to employment contracts and security interests, so that those effects might be governed by the same law as governs questions of validity and effectiveness of the claim, in the interests of parties who have relied on the particular economic and social context in that jurisdiction. ${ }^{81}$ Therefore it is desirable that there should, in some instances, be a modification of the choice of law rule, given the likely differences in laws relating to matters such as employment law,

\footnotetext{
78 See Paragraph 80-85 of the UNCITRAL Legislative Guide on Insolvency Law 2006

79 See Paragraph 91 of the UNCITRAL Legislative Guide on Insolvency Law 2006

80 These may include, for example: identification of the debtors that may be subject to insolvency proceedings; determination of when insolvency proceedings can be commenced and the type of proceeding that can be commenced, the party that can apply for commencement and whether the commencement criteria should differ depending upon the party applying for commencement; Constitution and scope of the insolvency estate; etc See further at: Recommendation 31 of the UNCITRAL Legislative Guide on Insolvency Law 2006 81 For instance, the insolvency effects over a right to set-off may be determined not by the lex fori concursus, but by the law applicable to the right to set-off. Other examples of exceptions to the application of the law of the forum that have been adopted by different insolvency laws address the law applicable to payment systems, labour contracts, avoidance provisions and proprietary rights. See further at: Paragraph 85 of the UNCITRAL Legislative Guide on Insolvency Law 2006
} 
between China and other jurisdictions. Such an approach would be likely to encourage cooperation while not undermining certainty unduly.

\section{(B) Application to Main Trading Partners}

An approach that is likely to encourage the adoption of the guidelines by China is the restriction to China's main trading partners. The most obvious starting point for China in this regard would lie with inter-regional cross-border insolvency cooperation with Hong Kong Special Administrative Region (referred to as HKSAR), which was mainland China's second largest trading partner in 2016. This selection of Hong Kong would provide a relatively easy start for China's cross-border insolvency cooperative approach. This is because, first of all, under the background of "one country, two judicial systems", HKSAR, as a region with the common law tradition, is more likely to establish a cooperation mechanism in cross-border insolvency with mainland China. ${ }^{82}$ Second, it is noteworthy that, thus far, the GITIC case was the first and the only insolvency proceeding opened in mainland China that was recognized by a foreign jurisdiction (the Hong Kong High Court). For this reason, the GITIC case may serve as evidence of potential reciprocity and so have a positive effect on mainland China and HKSAR's future cross-border insolvency judicial practices.

A cooperative outcome between the mainland and HKSAR can potentially be achieved by means of a bilateral agreement in accordance with Article 95 of the Basic Law of HKSAR. ${ }^{83}$ Various agreements in respect of judicial cooperation between Hong Kong and China have previously been achieved using this Article. None have yet concerned insolvency law but the development of such an agreement would seem a logical step, following the enactment of the EBL 2006. A bilateral agreement with HKSAR, would

\footnotetext{
82 See further at: Xinyi Gong, "When Hong Kong Becomes SAR, Is the Mainland Ready? Problems of Judgments Recognition in Cross-border Insolvency Matters" (2011) 20 IIR 57, 72-73

$83 \mathrm{lbid}, 73$
} 
enable the Chinese courts to gain valuable experience of cooperation in cross-border insolvency cases. This experience would not only have the potential to lead to the realization of greater levels of cross-border insolvency cooperation in the Region of Greater China, including Taiwan Island (the eleventh largest trading partner of China in 2016), ${ }^{84}$ but it would also potentially enable China to gain experience of cross-border insolvency cooperation with countries of the common law tradition.

It is also notable that China is the largest trading partner of the ASEAN, the Association of South East Asian Nations. China could arguably include specific provision for dealings with ASEAN. One possibility would be a provision that the relevant parties could use the EU Insolvency Regulation or the UNCITRAL Model Law as persuasive referential legislations in the event that cross-border insolvency problems occurring within the China-ASEAN Free Trade Area. For another instance, if the same problems happened between China and a member state of the European Union (the largest trading partner of China in 2012), the cooperation guideline could specify that the EU Insolvency Regulation or the UNCITRAL Model Law also could also be set as referential legislations on a persuasive but not binding basis.

Last but not the least, the cooperation guideline could stipulate that China could deal with cross-border insolvency problems with certain major trading partners by reference to the UNCITRAL Model Law in the situation where that major trading partner is one of the Model Law adopting countries. Among China's Top 10 trading partners in 2016, there are three Model Law adopting countries. They are the United States, Japan and South Korea. A compelling basis for this approach would be that the adoption of the Model Law by these countries is suggestive that cases would be approached on a reciprocal basis.

To sum up, formulating a cooperation guideline can be viewed as a transitional approach to the cross-border insolvency cooperation problems in

\footnotetext{
84 The Region of Greater China is a term used to refer to Mainland China, Hong Kong SAR, Marco SAR and Taiwan Island. Sometimes, it includes Singapore. This term is used merely for referring to the cultural and economic ties between the relevant territories, and is not intended to imply sovereignty.
} 
China, augmenting Article 5 and facilitating the resolution of cases in particular concerning China's main trading partners. Meanwhile, this guideline is also a beneficial supplement to the hard-law rules. Ultimately, the purpose of Stages 1 and 2 is to pave the way for the realization of Stage 3, which is China's formal adoption of the UNCITRAL Model Law.

\section{Stage 3: Formal Adoption of the UNCITRAL Model Law in China}

This part will address three logically related questions: whether China should adopt the UNCITRAL Model Law; the reasons why it has not yet done so; and the specific terms of any future adoption by China.

\section{Should China Adopt the UNCITRAL Model Law?}

After the previous two stages of the suggested developmental process, at the third stage, China could formally adopt the UNCITRAL Model Law as a longterm approach to cross-border insolvency. However, in doing so, account should be taken of China's unique political, economic, cultural and legal milieu. ${ }^{85}$ If a law is to be absorbed by China, it should arguably be Sinicized. That is arguably so in relation to every aspect of law and it is also so in the domain of cross-border insolvency. One notable factor is that China is still very much state-led in relation to its economy, politics and, of course, legal developments, and that, in spite of considerable progress having been made since 1978 in opening up its markets, China remains unwilling to enter into full and unreserved integration into the US-led globalization process. ${ }^{86}$ Instead, China is deeply convinced of the correctness of its prudent approach, selftailored to China's unique national circumstances and it has followed a gradual approach to integration with the trend of globalization. China is likely

\footnotetext{
85 See further Weiwei Zhang, The China Wave: Rise of A Civilizational State ( $1^{\text {st }}$ edn World Century, USA 2012)

86Mark Weisbrot, "2016: when China overtakes the US" (The Guardian official Website 27 April $\quad 2011$ ) <http://www.guardian.co.uk/commentisfree/cifamerica/2011/apr/27/china-imfeconomy-2016> accessed April 5, 2013
} 
to continue to pursue this approach in the future, including in relation to such version of the UNCITRAL Model Law as China may adopt. It is likely that there will be a period of transition, prior to the time of formal adoption, in which a cautious, tailored and gradual process will be undergone.

China, as one of the Member States of UNCITRAL, sent representatives to attend previous discussions about the Model Law but it has not yet adopted the Model Law. It is arguable that, if a suitable means of adoption can be found, China could repeal Article 5, following the example of the United States, which repealed Section 304 following its adoption of the Model Law. However, it is unlikely that this stage will be reached in the near future. China may wait one decade or even longer before the final realization of the formal adoption of the Model Law. It must be remembered that before the official promulgation of China's EBL 2006 on August 27, 2006, the Chinese legislators took about 12 years for the purpose of consultation and deliberation. Circumstances were not suitable for the enactment of this law to have taken place at an earlier stage and it was only when internal and external pressures for reform grew that legislative action was taken. ${ }^{87}$ The new law has been slow to have impact and it follows from this that developments in respect of cross-border insolvencies may yet be gradual and that significant progress will not be made until internal and external drivers again exert sufficient persuasion.

\section{Why Has China Not Formally Adopted the UNCITRAL Model Law Thus Far?}

Adoption of the Model Law could enhance the Chinese cross-border insolvency framework by providing a foreign insolvency representative, appointed in proceedings in a country in which the debtor has its COMI, with an avenue through which to seek the recognition of those insolvency proceedings in China. However, a combination of the nature of the UNCITRAL Model Law, the relatively limited success of the UNCITRAL Model Law and the special characteristics of China have arguably resulted in the

87 R Parry and H Zhang, "China's New Corporate Rescue Laws: Perspectives and Principles" (2008) 8 Journal of Corporate Law Studies 113 
outcome of the UNCITRAL Model Law not having been formally adopted in China thus far.

Although the UNCITRAL Model Law has attracted almost no negative comments on its provisions from the academic and practice circle, it is obvious that it has only achieved limited success in terms of "quantity of the Law's provisions that are adopted and quality of the implementation provisions as an accurate embodiment of their intended substance." ${ }^{8}$ This is because the UNCITRAL Model Law is not a hard-law treaty or convention but a non-binding soft-law text, which countries can freely choose whether or not to adopt, and, if adopting, they can do so with or without significant adaptation. It is notable that a nonbinding instrument of this nature is more likely to be favoured for adoption by countries of a common law tradition, rather than those of a civil law tradition, such as China. ${ }^{89}$ At the time of writing, twenty years after the adoption of the text of the Model Law, 44 countries and territories in the world have adopted the Model Law, with numbers having swelled considerably in 2015 through the collective adoption by the 17 OHADA countries.

The ability for a state to decide for itself how best to incorporate the Model Law is a factor that favours the adoption of the law, however it is also notable that exceptions and concessions have undermined the quality and effectiveness of adoptions ${ }^{90}$ and "the more changes that are made to the text of the Model Law, the less the harmonization effect of the resulting domestic legislation." ${ }^{11}$ Among those 44 countries and territories that have adopted the Model Law, there have been few who have done so without significant modification. For instance, in order to protect its national interest, South Africa adopted the most restrictive reciprocity provision which means that the

\footnotetext{
${ }^{88}$ Bob Wessels, "Will UNCITRAL Bring Changes to Insolvency Proceedings Outside the USA and Great Britain? It Certainly Will" (2006) 3 ICR 20,20-21; lan Fletcher, Insolvency in Private International Law: National and International Approaches ( $2^{\text {nd }}$ edn Oxford University Press, Oxford 2005) 486

${ }^{89}$ Asif Eirat, "Legal Traditions and Nonbinding Commitments: Evidence from the United Nations' Model Commercial Legislation" (2016) 60 International Studies Quarterly forthcoming $90 \mathrm{~S}$. Chandra Mohan, "Cross-border Insolvency Problems: Is the UNCITRAL Model Law the Answer?" (2012) 21 IIR 199, 203

91 lbid 209
} 
adoption of the Model Law is not an effective guarantee of reciprocity under the South African law. In addition, the "road" of the Model Law adopting countries after they have crossed the obstacle of adoption has not always been smooth, as discussed below.

Due to the special characteristics of China, the process of legal "transplanting" of foreign and international laws can be fraught with difficulties. Other civil law jurisdictions have adopted the Model Law but China would be likely to require particular modifications. Any legal transplantation must integrate foreign and international laws with Chinese realities and the Model Law would be no exception.

\section{What Might be the Macro Deviations of China's Adoption?}

UNCITRAL recommends that countries make as few changes as possible in incorporating the Model Law into their legal systems, in order to achieve a satisfactory degree of harmonization and certainty. ${ }^{92}$ In spite of this, several adopting countries have made deviations and it is arguable that China will adopt significantly restrictive terms if formally adopting the Model Law. In other words, China will continue to hold a very cautious and conservative legislative attitude. Possible restrictions and deviations are suggested by those taken by adopting nations so far.

The most likely deviation is a reciprocity requirement. It is suggested that reciprocity results in a view of a less cooperative approach to cross-border insolvency issues, ${ }^{93}$ and it is not a requirement that is included in the Model Law, yet this approach has been followed by several adopting countries. ${ }^{94}$

\footnotetext{
92 See Paragraph 20 of the Guide to Enactment and Interpretation of the UNCITRAL Model Law on Cross-Border Insolvency (2014).

${ }_{93}$ David Marks, "Review of 'Look Chan Ho (ed.), Cross-Border Insolvency: A Commentary on the UNCITRAL Model Law'" (2010) 4 ICR 278, 278

94 Keith Yamauchi, "Should Reciprocity be a Part of the UNCITRAL Model Cross-Border Insolvency Law" (2007) 16 IIR 145, 178
} 
The British Virgin Islands, ${ }^{95}$ Mexico, ${ }^{96}$ Romania, 97 South Africa ${ }^{98}$ and Mauritius ${ }^{99}$ have all included either an express reciprocity requirement or have restricted the law to designated countries. The latter limitation is particularly restrictive and, if no countries are designated, the Model Law fails to be practicably effective. In contrast, the US, UK, Canada ${ }^{100}$ and Australia have adopted the Model Law with no reference to reciprocity of any sort.

It is probable that if China adopts the Model law, China will include a reciprocity requirement, in order to limit the scope of application of the Law, given that Article 5 of the EBL is restricted in this manner. ${ }^{101}$ The conditions of reciprocity can vary but Westbook has identified two variations, positive reciprocity, under which regard is had to whether the courts of the requesting country are positively cooperative, and negative reciprocity, which permits courts to cooperate unless there is evidence that the other jurisdiction would not do so. ${ }^{102}$ It is likely that the adoption of the former, more restrictive, approach would be taken by China. However, arguably any state which had adopted the UNCITRAL Model Law without significant limitation ought to be taken as demonstrating positive reciprocity.

Less controversially, there is the possible exclusion of certain entities from the scope of application. Article 1 (2) of the Model Law contemplates the exclusion of certain types of entity, such as banks or insurance companies, for

\footnotetext{
${ }^{95}$ British Virgin Islands Insolvency Act 2003, s 437, confining the application of the law to designated countries.

${ }^{96}$ Commercial Insolvency Law, Art 280, applying the law except in cases where there is no international reciprocity.

${ }^{97}$ Cross-border Insolvency Law, Art 18.

${ }_{98}$ Cross-border Insolvency Act (42/2000), s 2, restricting the application of the law to designated countries.

${ }_{99}$ Mauritius Insolvency Act of 2009, Part VI.

100 Before Canada formally adopted the Model Law, a Canadian joint taskforce recommended that if the Model Law was to be adopted, the applicable provisions should include a reciprocity requirement that it would only apply with respect to a foreign insolvency proceeding if the applicable foreign jurisdiction had adopted the Model Law. This was because, if a crossborder insolvency were to occur within a country that had not adopted the Model Law, Canadian creditors could potentially be disadvantaged if the foreign jurisdiction were restrictive.

101 Xinxin Wang and Jianbin Wang, "Analysis About China's Acknowledging Extraterritorial Effect System of Foreign Bankruptcy Procedure and its Improvement" (我国承认外国破产程序 域外效力制度的解析及完善)' (2008) 6 LSM 10, 10-12

102 JL Westbook, "Theory and Pragmatism in Global Insolvencies: Choice of Law and Choice of Forum" (1991) 65 Am Bankr LJ 457, 468
} 
the reason that they are subject to special insolvency regimes in each country. However, almost all of the Model Law adopting countries' exclusions are very much wider than those that are contemplated by the Model Law. ${ }^{103}$ For instance, Great Britain excludes not only UK credit institutions and insurance companies but also European Economic Area (EEA) and third country credit institutions and insurance companies from the application scope. ${ }^{104}$ It is understandable that the former category of entities should be excluded but the exclusion of the latter category of entities has the possibility to trigger unnecessary inconsistencies in the law. ${ }^{105}$ Another example is the US, which excludes investment institutions, stock exchanges, insurance undertakings, clearing houses, brokers and traders, banks, railroads, stockbrokers and commodity brokers but not foreign insurance companies. ${ }^{106}$ The greater the range of exceptions, the more that the coverage of the Model Law is undermined and "it is unclear how excluding such a variety of institutions that have a potential to involve assets in multiple countries really serves the Model Law's purpose."107

It is probable that if China adopts the Model law, China will also follow in the US and UK's footsteps to exclude financial institutions from the application scope of the Chinese version of the Model Law, dealing with such institutions under specialised laws. This is not an unusual approach, internationally, but the insolvencies of financial institutions are sensitive in China, in particular given the important role which savings have played in Chinese culture. A rudimentary framework is established in Article 134 of China's EBL 2006, which is China's first legal provision enabling the opening of insolvency proceedings in respect of financial institutions. This article applies to "financial institutions including but not limited to commercial banks, securities companies, insurance companies", which meet the tests of Article 2 of the law.

\footnotetext{
${ }^{103}$ S. Chandra Mohan, "Cross-border Insolvency Problems: Is the UNCITRAL Model Law the Answer?" (2012) 3 IIR 199, 211

104 Look Chan Ho, Cross-border Insolvency- A Commentary on the UNCITRAL Model Law

(3rd edn Global Business Publishing Ltd, London 2012) 144

$105 \mathrm{lbid}, 144$

106 See Section 1501 of Chapter 15 of the US Bankruptcy Code

107 S. Chandra Mohan, "Cross-border Insolvency Problems: Is the UNCITRAL Model Law the Answer?" (2012) 3 IIR 199, 211
} 
It provides that a petition for reorganisation or liquidation may be presented to the People's Court by financial supervisory and regulatory institutions under State Council, rather than by the debtor or its creditors. It may be noted that this remains an area in which state control is retained, even if it has ostensibly been removed elsewhere. The Article provides that if the financial supervisory and regulatory institution under State Council takes over a financial institution with material business risks or takes it under custody, it may petition the People's Court to stay civil litigation procedures or execution procedures in which the financial institution is the defendant or the party against which the execution procedure is filed, as the case may be. Naturally, one article is insufficient to address this complex issue and implementation measures are to be formulated in accordance with the EBL and other relevant laws. ${ }^{108}$ The State Council of China first proposed to enact special legislation in respect of financial institution insolvency in its 12th Five-Year Plan for the Development and Reform of the Financial Industry in 2012. ${ }^{109}$ There have been few subsequent developments. The latest development was the Deposit Insurance Regulation which was promulgated for implementation as of $1^{\text {st }}$ May 2015. We can see from the above two points that the development of a specialist framework for such insolvencies, under a similar approach to that taken in the US and UK, will probably lead to the exclusion of financial institutions from the application scope of any future Chinese version of the Model Law.

More generally, a public policy exclusion is likely. Article 6 of the Model Law stipulates that the court of the enacting country can refuse to recognize a foreign judgment or the application of foreign law if the action would be "manifestly" contrary to the public policy of the enacted country. ${ }^{110}$ The word "manifestly" indicates that the public policy "exception" is limited only to the

\footnotetext{
108 See Article 134 of the EBL 2006

109 See further at: "12th Five-Year Plan for the Development and Reform of the Financial Industry" released by the China's State Council on September 17, 2012. With the aim to improve the financial system and promote the continued healthy development of the financial industry the "12th Five-Year Plan" was jointly formulated with the People's Bank of China, the China Banking Regulatory Commission, the China Securities Regulatory Commission, the China Insurance Regulatory Commission and the State Administration of Foreign Exchange. 110 See Article 6 of the UNCITRAL Model Law
} 
situation where the foreign insolvency judgment is contrary to the most fundamental policies or rights of the state. ${ }^{111}$ Some adopting countries, such as the UK, US and Australia, have followed Article 6 of the Model Law verbatim. However, some other adopting countries, such as Canada, have omitted the word "manifestly" while adopting Article 6 of the Model Law. The Canadian version of the Model Law gives Canadian courts greater discretion since it merely stipulates that the Canadian courts can refuse to do something that would be contrary to public policy, not "manifestly contrary to public policy". ${ }^{112}$ China, as one of the Member States of UNCITRAL, "wanted the word "manifestly" to be removed from Article 6 but it was not able to persuade the Working Group to agree."113 Obviously, it is likely, in view of this, that the word "manifestly" will be omitted as a qualifier in such Chinese version of the Model Law as may be adopted in future, giving the courts greater flexibility to refuse to recognise foreign proceedings.

Another issue is whether the adoption of the Model Law is a replacement for other cross-border insolvency laws (such as possible country-specific measures discussed in Part III above) or, as in the UK, whether it will added a further option to a menu of cross-border insolvency laws. ${ }^{114}$ In view of space limitations and the logical structure of this article, the details of each will not be dealt with here. ${ }^{115}$ To sum up, the final realization of Stage 3 of the development of China's cross-border insolvency legal regime would entail China's formal adoption of the UNCITRAL Model Law, although it is submitted that this development might take at least a decade.

\footnotetext{
111 Look Chan Ho, Cross-border Insolvency- A Commentary on the UNCITRAL Model Law (3rd edn Global Business Publishing Ltd, London 2012) 177

112 lbid 81

113 S. Chandra Mohan, "Cross-border Insolvency Problems: Is the UNCITRAL Model Law the Answer?" (2012) 3 IIR 199, 212

114 IG Williams and AJ Walters, "The Model Law: Is It Time for the U.K. to Change Tack?" (2016) 35.1 American Bankruptcy Institute Journal 16.

115 S. Chandra Mohan, "Cross-border Insolvency Problems: Is the UNCITRAL Model Law the Answer?" (2012) 3 IIR 199, 214. There are also a number of common and significant micro cooperative form deviations such as "the recognition of foreign proceedings, the granting of interim reliefs...the coordination of multiple proceedings and the ranking of claims of foreign creditors in different countries", which are beyond the scope of this article.
} 


\section{Conclusion}

Domestic Chinese insolvency law remains in its infancy. State control of proceedings may have, looking at legislation on the surface, been cut back but the limited impact of the new insolvency law suggests that considerable control remains, in practice and behind the scenes, in spite of rising numbers of cases. Moreover, overseas creditors may be reluctant to use such a rudimentary law and it is likely that filings in China will be avoided by such creditors where possible. It follows that a cautious approach will continue to be taken in respect of Chinese cross-border insolvencies. The only crossborder insolvency provision in the Chinese EBL 2006, which is Article 5, merely provides a starting point for the consideration of this complex area of law and this article has suggested a three stage process for further development of this area of law, reflecting the incremental approach to law reform that has taken place in other areas. The first stage is to complete the domestic provision by the issuing of a judicial interpretation for the purpose of legally clarifying the uncertainties in Article 5. The second stage is to formulate a cooperation guideline of a soft-law nature, to deal with both inbound and outbound cross-border insolvencies involving key trading partners. The third stage is the formal adoption of the UNCITRAL Model Law in China, although in a greatly modified form, reflecting some of the restrictions made by other jurisdictions. 